\title{
The concept of violence in (times of) crisis
}

\author{
On structural, institutional and anti-institutional violence
}

\author{
Marilena Drymioti
}

\begin{abstract}
"Every violence appears 'in context'.
Violence exists only within a framework.

Violence is a product of circumstances."

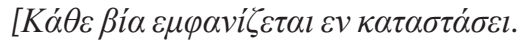

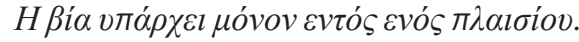

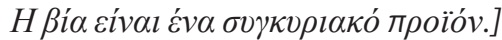

(Labica, 2014: 60).
\end{abstract}

During the last decade in Europe, and more specifically in what is regarded as the European South, ${ }^{1}$ it was observed that the extreme version of austerity politics employed to overcome the crisis of 2008 unleashed strong reactions including violent protests, clashes with the police, scuffles between political groups and acts of vandalism against public property among other acts of opposition. As widely reported by academics, analysts, journalists and activists the Greek context did not stand as an exception. Since 2010, when the Greek government of George Papandreou officially announced that Greece is facing a severe crisis, the numerous changes witnessed in mainstream politics and the overturn of established political discourses marked also the manifestation of a social conflict which in many instances was experienced or, expressed as violence.

Mainly due to poor GDP growth, excess government spending and significant rise of budget and trade deficits, Greece was called in 2009 to face one of the most severe crises in its history. In co-ordination and under the supervision of TROIKA, ${ }^{2}$ the Greek governments in power since 2010 signed in total three memoranda of co-operation ${ }^{3}$ which required the implementation of numerous measures regarded as necessary for the stabilization of the economy. The measures were implemented in packages over the years and concerned almost every sector that could influence the quality of life of Greek citizens (e.g. health, education, housing, work, social security and pensions). Greece was called to accomplish the

1 Usually referring to Greece, Italy, Portugal, Cyprus and Spain.

2 TROIKA is a committee consisting of the European Central Bank, the European Commission and the International Monetary Fund, formed to provide financial support and guidance to the Eurozone members mostly struck by the Financial Crisis of 2008.

3 Also known as: Economic Adjustment Programs. 
most rapid and large fiscal adjustment on its GDP in the Eurozone. ${ }^{4}$ As openly admitted by the IMF, due to wrong calculations and intra-TROIKA disagreements, the measures implemented during the first years of crisis (approx. 2010-2012) resulted to the magnification of the Greek debt. ${ }^{5}$ As a result, new measures had to be implemented including further reductions and cuts in public spending, practically meaning less support and diminished service provisions from the state to the citizens. Besides the purely economic (in terms of numeral calculations) side of the story and the hundreds of reasons that led Greece to face a severe crisis in 2009, the study of the conflictual relationship which resulted out of the crisis among all the actors involved - either found at global, regional or national level - is particularly intriguing.

A term commonly used during the last decade of crisis in the public and political discourse that indicates the existence of a conflict is the term 'violence'; used by citizens in order to support that 'what we experience is violence', used by media to refer to protests and mobilizations that ended in 'violent clashes between the police and the participants', employed by protestors through the use of the old known (at least for the Greeks) slogan of the radical left 'violence to the violence of power'. Both austerity measures introduced by the Greek state and the reaction of Greek people could be identified as acts which share two common characteristics; namely, both being political and having a violent nature. The political dimension of the aforementioned acts is an easily assigned characteristic considering that the enforcement of austerity measures reveals a neoliberal political direction and the reaction of the citizens comes as a stance of opposition. The second characteristic, namely the violent nature, is often automatically ascribed to the acts of opposition. However, politico-economic measures are still hardly conceptualized under theories and concepts used to explain and understand violence.

Based on literature which argues that certain politico-economic measures could be considered as violent mainly due to their effects on a specified population (see Galtung, 1969; Farmer, 2004; Cooper and Whyte, 2017; Böhm, 2018), this paper suggests that austerity could be studied under the conceptual umbrella of vio-

4 "A record fiscal consolidation by OECD standards has reduced the deficit, pension and health care reforms have enhanced longer-term fiscal sustainability, and structural reform has improved labour market flexibility and cost competitiveness. However, the adjustment programme agreed in 2010 between the Greek authorities, the International Monetary Fund, the European Commission and the European Central Bank has not yielded the expected results in restoring activity, which has been hit much harder than in other euro zone countries with adjustment programmes, such as Ireland, Portugal or Latvia (which has a euro peg). This has worsened the debt problem, despite the debt restructuring that took place in 2012, while unemployment has sharply increased. Restoring growth, making it sustainable and dealing with social costs are essential to the success of the adjustment programme." (OECD, 2013: 3), OECD Economic Surveys Greece, November 2013, Overview. Retrievable at: www.oecd.org/eco/surveys/ GRC_Overview_Eng_2013.pdf.

5 "The report argues that IMF staff knew imposing a fiscal squeeze on Greece would be especially painful, but failed to translate that into their growth forecasts, assuming a low 'multiplier' from tax rises and government spending cuts." (Financial Times, 2013). Retrievable at: www.ft.com/ content/6924ee76-cdfb-11e2-8313-00144feab7de. 
lence. As violence committed by the state through measures and regulations is often academically termed as institutional violence, the concept of anti-institutional violence seems to describe the reaction of Greek citizens more accurately than any other term used for the study of oppositional social action. Accordingly, during the acute economic recession and political upheaval in Greece, two main forms of violence seem to have developed, namely institutional (coming from above, the state) and anti-institutional (coming from below, the citizens). Nevertheless, structural arrangements should not be neglected in the study of global phenomena such as the financial crisis and its lived reality. Consequently, due consideration should also be given to abstracted notions of violence such as structural violence.

The paper does not seek to produce a new theory or reconceptualize structural violence, institutional violence, and anti-institutional violence. Rather, it aims to discuss the already existing knowledge and put it in context, in an endeavor to explore how violence could be understood and studied in recent times of crisis and conflict. The first section, highly inspired by De Haan's (2008) paper on violence as an essentially contested concept, employs a narrow discussion on the existing framing of the concept of violence in general. The second section provides a more analytical understanding on the way the forenamed forms could be perceived to better fit the context of Greece during the last decade. As a conclusion, a brief overview of the ideas discussed in previous sections will be provided.

\section{Conceptual framing}

Willem de Haan, referring to Gallie's paper on the essentially contentedness of concepts (1956), argued that violence falls into the category of concepts that debates around its substance, definition and methodology can never reach closure (De Haan, 2008: 29). For almost every scholar that studies violence, it becomes quite apparent that it is a concept the scientific community will never come to an agreement about. The only agreement that we can possibly reach in the first place is that, as Levi and Maguire wisely put, violence is "a slippery term" (2002: 796). The reasons why violence is a contested concept vary. To start with, it is a concept that invites various scientific disciplines to study and make sense of it. That leads to a plethora of approaches, definitions, explanations and methodologies which in certain instances are inconsistent. Brubaker and Laitin more specifically noted that "the problem is not that there is no agreement on how things are to be explained; it is that there is no agreement on what is to be explained, or whether there is a single set of phenomena to be explained" (1998: 427). Even though there is a disagreement over the available explanations of violent performances as well, the major problem in the study of violence is, indeed, whether certain performances are 'capable' of being named violence at the first place.

In his prominent work Violence as an Essentially Contested Concept, Willem de Haan (2008) offered a valuable outline on (some of) the available definitions of violence. He is discussing some of the most restrictive as well as the most inclu- 
sive definitions that are available in the literature. Most of the times the discussion is around the necessity, or not, of a physical act to be in place in order to talk of violence, the harm as a necessary outcome and the assigned legitimacy to the performance under question. The discussion suggests that depending on the form of violence studied, the three main denominators mentioned above - physical act, harm, legitimacy - are equally subjected to different analysis and understandings. For instance, the initial focus on merely violent physical acts is regarded as arbitrary and untenable in studies on structural, symbolic, institutional, cultural and psychological violence - to name a few examples of non-physical violence (see Barak, 2003; Schinkel, 2005).

As regards the notion of harm, any suggestion that a performance will only be considered violent if the harm caused is of a physical nature, in most cases inherently requires a physical attack to be in place as well. Since in cases of non-physical violence the possibilities of having physical harm as an outcome are limited, in practice we fail to take into consideration a wide pool of non-physical harms which can still be products of violent performances. Henry noted in his work on school violence that conventional approaches will inherently hold us liable to "ignore what some consider to be the equally important hidden crimes of the structurally powerful in society (Henry and Lanier, 1998), and the symbolic social harms that deny humanity through violating human rights (Henry and Milovanovic, 1996)" (Henry, 2000: 18). In the same line of thinking, he also noted by referring to Bourdieu (1977) that conventional understanding on harm as merely physical,

"First, it excludes the emotional and psychological pain that result from domination of some over others. Second, it tends to focus on the visible, intentional, interpersonal harm between individuals, while excluding harm against individuals by institutions or agencies. Third, it ignores the violence of social processes, which produce systematic social injury, such as violence perpetuated through institutionalized racism and sexism. Fourth, it excludes the 'symbolic violence' of domination... (Bourdieu, 1977: 192)” (Henry, 2000: 2).

In the course of this debate, among the most abstracted understandings of harms that could possibly be the result of violence, are the harms of reduction and the harms of repression (Henry and Milovanovic, 1996: 103). The former referring to the action of removing "something from a person's existing standing as a human being" whereas the latter "reveal how the exercise of power acts to systematically limit another person's capability of achieving higher levels of accomplishment along any of these dimensions [physical, material, psychological, social and symbolic, moral and ethical]" (Henry, 2000: 20). As Henry explained, the aforementioned forms of harm could be the outcome of actions as well as processes and, could be committed by individuals as well as communities, organizations, corporations and the state (ibid.). Thus, violence could be "the use of power to harm another, whatever form it takes" (ibid: 3 ). 
Undoubtedly, the introduction of the notion of power to the definition of violence is essential, especially in the study of politically relevant violent performances. Ruggiero, in his book Understanding Political Violence: A Criminological Analysis (2006), describes political violence as the violence used to administer key political objectives and achieve political goals typically aimed to either bring or restrain social change. As suggested, it can be sponsored and/or committed from the top level of society as well as the bottom. It can be authorized and unauthorized or, institutional and anti-institutional. Institutional violence amounts to law-making or law-conserving violence which through the use of authorized force aims to either designate a new authority while changing the current system, or to sustain the already established system and reinforce authority (Ruggiero, 2006: 1 and Ruggiero, 2017: 3). On the other hand, anti-institutional violence is characterized by the use of unauthorized force which as any 'anti-'initiative aims to oppose established arrangements such as authority (Ruggiero, 2006: 1). What is important at this stage of the paper is the division between violent performances that make use of either authorized or unauthorized force. That division is similar to the distinction between legal and illegal violence. Since cases where authorized force is used tend to be characterized already by a degree of legality, they are unlikely to be easily accepted as cases of violence. In contrast, the concept of legitimacy is employed by many academics in an attempt to suggest that harm can be the product of legal arrangements as well.

De Haan in his analysis referred to the anthropologist David Riches who in 1986, even though still referring to physical acts, incorporated into his definition of violence the concept of legitimacy. Riches termed violence as "an act of physical hurt deemed legitimate by the performer and illegitimate by (some) witnesses" (Riches, 1986: 8 in de Haan, 2008). The introduction of the concept of legitimacy is promising and could be valuable in the examination of various forms of violence but then, a rather critical question arises; who determines what is legitimate and on what grounds? An argument in favour of the examination of violence through the concept of legitimacy could be that the 'existence' of the witness works as a buffer to ensure that no matter how the performer perceives their actions, if the witness considers the act as illegitimate then the performer will be held responsible of a violent performance. However, this argument suggests that violence is "unlikely to be mistaken" considering that people share a common understanding on what constitutes of illegitimate performances of violence (de Haan, 2008: 30). By merely examining violence through the concept of legitimacy we run the risk to simply play among perceptions; the perceptions of the actors involved since the judgement of an act as illegitimate or not, will always depend on whether they share different ethical, moral, ideological, political and social values (see De Haan, 2008: 4-5). Moreover, we run the risk of overlooking that in certain cases the power dynamics are unequal between actors involved in violent interactions. In Weberian terms, modern states are monopolizing the use of legitimate violence (force) thus, no matter the effects or consequences of a violent performance sponsored by the state, the use of force is always authorized and regarded as legitimate (Weber, [1919] 2015). Bourdieu ([1984] 1988), further developing Weber's 
concept of the monopoly of legitimate violence, argues that the state monopolizes symbolic violence as well, through the production and classification of 'legitimate identities' which justify procedures of inclusion and exclusion at a societal level usually at the expense of certain social groups (see Sapiro, 2015). Accordingly, the state is not merely monopolizing the use of legitimate violence, but it becomes the machinery within which violent performances sponsored by certain social groups are more likely to be regarded as legitimate than violent performances sponsored by other less powerful groups. Thus, the state does not merely enjoy immunity when comes to question its own violent actions but, most importantly, it acquires the role of the main 'witness' determining who has the capacity of exercising legitimate violence and on what grounds. However, is the state the sole actor that has the power to decide what is legitimate or not in specific contexts? Or, could it be said that our current political context is one in which extrastate actors exert an equal if not greater power than state actors to perform legitimate violence at the expense of certain social groups? The text will turn to these questions in the following section.

The most important argument resulting from the discussion thus far, is that the never-ending process of trying to fit every form of violence under a single definition based on strictly conceptualized denominators completely disregards its multidimensional and constructed nature. All discussions on what to include or exclude from the definition of violence miss an important component of the notion; violence is not merely socially but most importantly politically constructed - if one can differentiate between the two. Violence is thus a political concept, insofar as the one who is able to 'officially and legally' label a certain performance/act/process/situation as 'violence' is the one who has the hegemony to either criminalize it, or make it a common and legitimate practice. At the same time, the one that is not in a hegemonic position and unable to officially decide what violence is, still has the capacity to 'unofficially' label a performance/act/ process/situation as 'violence' and react, opposing the hegemonic understanding around the notion. Having as a starting point that violence is an empty signifier, for it can be filled with many meanings depending on who is using it, in which context and under what circumstances, this paper aims to reopen a theoretical discussion on the notion of violence along the lines of three very extended concepts; namely, structural, institutional, and anti-institutional violence.

\section{Conceptual 're-framing' based on contextual specificities}

\section{On structural violence}

Johan Galtung is not coincidently the name most referred to in every academic discussion on structural violence. Galtung, in his prominent work Violence, Peace and Peace Research, marked the beginning of peace and conflict studies. Most importantly, he introduced a landmark concept in the study of violence that was meant to change our understanding of who and what is capable of committing violence. In his paper Galtung advocates on the definition of peace which as he 
noted is not the mere absence of war or conflict, but also the absence of violence - both direct physical violence and indirect structural violence (Galtung, 1969). Focusing on his notion of indirect structural violence, it occurs when an unidentified actor - meaning not a single human being - commits violence not directly against an object, but rather, by influencing the available resources, income, education and health at a degree that negatively influences the standard of living (Galtung, 1969: 171). Numerous scholars have worked on the concept of structural violence since the introduction of the concept by Galtung, some offering very general definitions and some more detailed. For example, Benson defined it as "social arrangements that systematically bring subordinated and disadvantaged groups into harm's way and put them at risk for various forms of suffering" (Benson, 2008: 590). Others defined it as "the systematic exclusion of a group from the resources needed to develop their full human potential" (Mukherjee et al., 2011: 593). Accordingly, structural violence is generally understood as an arrangement deeply rooted in a system of relationships within a socio-economic and political apparatus that results in the restriction of enjoyment of fundamental rights to the degree that certain social groups are constrained from achieving the quality of life that would have otherwise been possible. To put it simply, structural violence is "the violence of injustice and inequity" (Rylko-Bauer and Farmer, 2016: 47). However, an important question arises here. What kind of harm needs to be in place to talk of violence and, more specifically, of structural violence?

The type of harm that needs to be identified in order to speak of structural violence is usually referred to as social suffering (Kleinman, Das and Lock, 1997). As Singer and Erickson noted, while the outcomes of structural violence are "experienced individually, structural violence targets classes of people and subjects them to common forms of lived oppression. Hence, the experience of structural violence and the pain it produces has been called 'social suffering'" (Singer and Erickson 2011: 1). Thus, through the term social suffering we talk of the exposition of the linkage between what is regarded as personal problems with societal and structural problems. It captures the lived experience of inequality and injustice that comes through the restriction of basic human needs (rights) like food, clean water, housing, healthcare, through the limitation of employment opportunities or the exposition to dangerous employment conditions as well as through severe cuts in pensions and public benefits. In the same line of thought, and especially for the purposes of this paper, social suffering could also be understood as the detrimental effects on peoples' life resulting from "rampant economic inequality, social exclusion, and persistent poverty arising from the imposition of neoliberal economic policies" (Sanchez, 2006: 179; see also Quesada, 2009) - namely, structural adjustment programs often linked to austerity politics and economic disenfranchising. As a recently published research on the Greek economic crisis highlighted, "in reality, the consequences of the countermeasures were devastating to the real economy and so forth to real life. The social cost of the countermeasures was severe, particularly regarding wellbeing. Many people cannot buy even a loaf of bread or a bottle of milk. Others search for food in garbage bins and there are many beggars and homeless in the streets. Recession turned to depression" (Mavridis, 2018: 6). One might argue that this 
quote is overly dramatic and probably not reflecting the Greek reality of crisis. Certainly, not every Greek citizen struck by the crisis searches for food in garbage bins. However, stories of people unable to sustain themselves cannot be seen as purely exceptional. The outcome of austerity measures implemented in Greece in the last decade was detrimental to the degree that invoking social suffering constitutes a valid argument. Nevertheless, how does one draw the link between social suffering and structural violence? To put it differently, how do structural forces and dynamics/changes found at a micro-societal level relate?

Considering that the imposition of austerity measures was 'ordered' by the current politico-economic arrangements that exist on a global scale, the outcomes of those measures at a societal level are up to a certain degree the product of that same structure. Accordingly, structure shapes the situations in which individuals act and experience their everyday life and microstructures are far from isolated; they are in fact highly influenced by macrostructures in terms of social formation and reformation, action and reaction. However, the degree of 'responsibility' assigned to the structure for changes found at the societal level is again bargained and discussed through the use of the concept of legitimacy.

Willem Schinkel in his analysis on the contemporary regimes of violence which he also refers to as regimes of regulation, offered very interesting insights on how the liberal state employs "a logic of attributing and distributing violence and its legitimacy" that works "as a technique of social sorting, of governing in the medium of violence, by ascribing and disavowing each one's violence" (Schinkel, 2013, 320). Part of his analysis is based on the argument that liberal states mainly recognize two different types of violence: private and state violence. While private refers to an active illegitimate violence performed by individuals, state violence is regarded as the legitimate reactive form of violence performed as a response to private violence (Schinkel, 2013: 318-320). His analysis continues through the argument that there is a third form of violence in contemporary regimes, which completes the triptych of what he called the trias violantiae, and that form is structural violence. Referring to Bourdieu's law of conservation of violence (Bourdieu, 1997: 275 in Schinkel, 2013: 320), Schinkel explains that structural and symbolic forms are considered by the liberal state as private illegitimate forms of violence that function out of the state's legitimate use of force. By merely recognizing structural violence as private and illegitimate, the state actually naturalizes social problems and ascribes the responsibility for their manifestation to the individual. Homelessness stands as a visceral example of structural violence that is naturalized and deflected as an individual problem by the state. In that way, the state detaches itself from any systematize and structural process that brings social injustice, by assigning the responsibility to individuals who fail to 'keep up' and correspond to current structural arrangements.

In order to counter the argument that social suffering is the result of individual choices and expose the linkage between what is regarded as personal (private) problems with societal and structural problems, one should first understand how institutions restrict the enjoyment of fundamental rights to certain social groups 
to the point that are constrained from achieving a certain quality of life. In the following section, a discussion on the concept of institutional violence will be provided in an attempt to explain how legitimate forms of violence mainly performed by formal institutions contribute to the manifestation of structural violence. More specifically, it will be argued that formal institutions are the way through which socially harmful arrangements are normalized and become a legitimate practice irrespective of their effect on specific populations.

\section{On institutional violence}

Starting with the term institution, it commonly applies to both social institutions such as customs, norms or behavior patterns important to a society, and to formal institutions created by entities such as the government, public services, universities, banks etc. Not surprisingly, the notion of institutions can often be confused with the notion of structure, since they both govern the behavior of individuals within a given community. Institutions are often identified as having the capacity of transcending individuals' intentions and experiences by mediating the rules that govern social behavior. However, structure is not simply the mediator, but the rules themselves; structure is a system. For that reason, it is possible to argue that institutions work as the medium in terms of communication and execution between structural/macro and micro scale dynamics.

Important to this section's analysis is to highlight that the degree of human agency embedded in the two often confused forms of violence differs. Galtung's original definition of structural violence is characterized by a lack of human agency. As presented in the previous section, scholars working on structural violence merely attempted to link personal suffering with political, social and cultural arrangements. Galtung was referring to an unidentified actor that shapes economic, political, religious, cultural arrangements in a way that it produces social injustice and inequity. Therefore, structure has the power to set some orders on how those arrangements should work, but a certain degree of acting is necessary in order to put those orders into force. That degree of acting can be identified and enforced through institutions. As noted by Winter and Leighton, structural violence is "embedded in ubiquitous social structures [and] normalized by stable institutions and regular experience" (Winter and Leighton, 2001: 99). Depending on the arrangement found at a structural level, normalization or execution usually originates in institutions that have authority over the particular subjects that the arrangement concerns. For example, for the purposes of this paper the referred structural arrangements concern political and economic policies thus, that the main focus at an institutional level will not be on social, but rather on formal institutions. Formal institutions consist of the government, public services, banks and any other formal mechanisms responsible for political and economic rule-making and enforcement.

Getting to the discussion on how institutional violence is conceived for the purposes of this paper, as Cooper and Whyte put it, "this is a form of violence that can be understood as a means of force which is not simply acted upon, but organized and 
administered through legitimate means" (2017: 23). It can therefore be understood as a legitimate form of violence performed by a set of institutions. Cooper and Whyte described the violence of austerity or, as they said, the violence of politics - a form of violence that was primarily caused due to decisions taken by institutions - as "a bureaucratized form of violence that is implemented in routine and mundane ways" (ibid: 3). As they further noted, formal institutions are not merely responsible to materialize abstracted politico-economic arrangements, they are, rather, "the very sites through which highly political strategies like austerity are depoliticized and their harmful outcome made to appear normal and mundane" (ibid.).

Even though the defenders of austerity praise it as a panacea for economic readjustment that would eventually bring development, thus far the implementation of austere measures during the last decade marked the failure to protect almost all spheres of Greek citizens' social life. Austerity is targeting the areas of public spending that protect the citizens from threats to their wellbeing and quality of life, unravelling in that way the whole system of social protection. Decisions related to austerity usually concern privatization, housing, education, public healthcare, pensions, employment, and public benefits, among other sectors. Philosopher John McMurty talking on the redistribution of resources from public to private hands - which, along with the severe public spending cuts, is another side of austerity politics - noted that "the signifiers of its agent do not disguise the underlying violence of the appropriation - 'axing social programmes', 'slashing public services', 'subjecting societies to shock treatments' and so on" (McMurty, 1999: 115 in Cooper \& Whyte, 2017: 17). Therefore, those most affected by austerity are not only struggling under a financial strain. More importantly, they are victimized by the institutions that are originally in place to protect their rights and secure them a certain quality of life. Whether the negative outcomes of austerity are measured by politicians as collateral damage or by economists as negative externalities, it is time to explore whether the turmoil caused to the lives of thousands of people affected by austerity had profound violent outcomes up to the point that the institutions implemented the measures can be identified as having violent capacities (Cooper and Whyte, 2017: 3).

Numerous important problems arise with the concept of institutional violence that need to be addressed. Firstly, to argue and convince that institutions and people of respect and status act in a violent way towards the people. One of the reasons that institutional violence differs from other forms is that the central actors are formal institutions represented by people of respected status, educated people and, in most cases, people democratically elected by the citizens. As put by Cooper and Whyte "the violence of austerity is not delivered by 'street gangs' or by the individuals that are typically the focus of public anxieties and tabloid moral panics. The violence of austerity is delivered by smartly dressed people sitting behind desks" (2017: 23). For exactly the same reason, it is also easier - and up to a certain degree convenient - to assign the responsibility for the negative outcomes of institutional decisions to the structure. To either blame the invisible hand or to simply stick to the explanation 'unfortunately, it is what it is'. Nevertheless, it was not an invisi- 
ble hand that signed the policy papers, that negotiated for months over the same policy papers, that defended certain policies, that is still refusing to change plans when it has been evident for a decade now that austerity is not working.

Given this fact, a second problem emerges, which is normalization of the state of crisis. If we agree that certain decisions taken by institutions have detrimental effects on the people we talk of institutional violence, the fact that those decisions are normalized in the current European and global discourse renders any argument in favor of considering those decisions as a form of violence impotent. An advocative factor of this process of normalization, and as a result the failure to see the 'violence' in it, is that the negative outcomes of those decisions are not always immediately visible. Institutional violence does not always inflict sudden pain or loss, rather it unfolds over time; in this sense, it can also be understood as slow violence (see Nixon, 2011). However, it was already a decade ago that austerity measures started to be implemented, and thus the argument of non-visibility loses its explanatory power. One might even argue that a decade is enough time to see whether the detrimental outcome was necessary in order to 'give a boost' to the economy. Unfortunately, this is not happening. On the contrary, the negative outcomes are deteriorating if not multiplied at a social level. A vivid example is the high number of claims submitted to the Greek Ombudsman regarding social security, social welfare, taxation and cases of forced execution for debts to the state in the years of 2017 and $2018 .^{6}$

Willem Schinkel criticized social sciences for failing to see other forms of violence besides the 'commonsensical' usage of the concept (which refers to intentional physical harm) due to analyses that stem back to "historical processes of state formation' based on the idea that the state enjoys the monopoly of power (Schinkel, 2013: 310, 311). In recent times of political and economic globalization what we experience is the decentralization of the state, highly impacting its capacity to monopolize power. The introduction of austerity measures in Greece involved a variety of actors and institutions found at different 'scales'; from Troika, which is a supranational committee, to the local Greek government and other national institutions. Moreover, besides the national/international binary we also have to pay due attention to the private/public binary. Banking institutions, private organizations and corporations also had, if not a saying, a degree of interest over the introduced measures. Going back to the discussion on whether the liberal state accepts structural violence as a product of its own way of functioning, the actual process of decentralization and the involvement of multiple actors in the decision making process that concern the national as much as the global, works in favor of the argument that any problem arising at the social level is due to the personal failure of the individual to cope with current structural arrangements. As a counter-argument, one might suggest that the introduction of new actors in the decision making processes does not seem to 'interrupt' the old known monopoly of who can perform violence in a legal and legitimate way. Rather, we are now

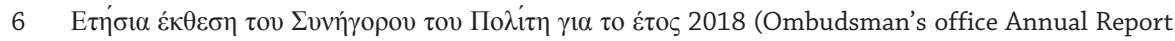
2018). Retrievable at: www.synigoros.gr/?i=kdet.el.ehtisies_ektheseis_documents.559298. 
experiencing an oligopoly of violence where more and more institutions are capable of exercising their violent capacities if regarded as necessary. Thus, instead of accepting that the individual is the one responsible to cope with current structural arrangements, we might need to talk of an assemblage of powerful institutions that make up the 'new state' and are equally responsible for negative social outcomes that might result out of their actions/decisions.

"The very act of law enforcement reproduces violence, albeit a violence of a different sort and in a different guise" (Schinkel, 2013: 317). During the last decade, the measures agreed either at national or EU level for the stabilization of the Greek economy were transformed into national laws and provisions. The citizens were then called to adapt to this new state of art and comply with the new arrangements. The enforcement of those measures which aimed towards to the establishment of a new structure resulted in an immediate response from Greek citizens. The reaction of the citizens will be discussed in more detail in the following section. However, what is important to note at this point is that their reaction is being labeled as illegitimate violence while the situation they reacted upon is (officially) not regarded as violent. The reason is, as discussed already, related to the legitimacy assigned to each action. Officially imposed measures are a legal and legitimate means of performing violence no matter their effects on the people while every reaction towards those measures is usually associated with 'crime and violent opposition against authority' (Ruggiero, 2017: 2). The main point of the above passage is not to extract any violent aspect of oppositional social action, but rather to challenge the hegemonic understanding of violent performances and acknowledge that formal institutions might be the initiators of violent performances as well.

\section{On anti-institutional violence}

Cooper and Whyte, in the introduction of their book The Violence of Austerity, characterize austerity as a three-part deception. The deceptive logic of austerity is based on the following three statements: 'we all played a part in the crisis', 'austerity is necessary' and 'we are all in it together' (2017: 5-15). However, it seems that people affected by austere measures do not agree with the aforementioned major statements usually invoked by the advocates of austerity. On the contrary, the failure to properly support and protect those people exacerbates and gives the necessary ground for other forms of violence to arise; from collective to individual, from oppositional to interpersonal, from gendered, racist to politically driven. This section will focus on a form that aroused as a response, as a stance of opposition to the politics of austerity. That particular form of violence could be termed anti-institutional and it refers to any action which designates unauthorized force addressed against the authority (see Ruggiero, 2006); a form of violence characterized by, or, expressing opposition towards formal institutions. As Ruggiero noted, referring to Smelser (1963): "it is true that aggrieved people are always likely to be driven into hostile outbursts, but under certain circumstances it is the institutions themselves that 'invite' people to display hostility" (Ruggiero, 2017: 2). Therefore, the great extent of frustration, anger, distress and insecurity that 
came as an aftermath of the 2008 financial crisis led to the genesis of individual actors as well as movement groups in the neoliberal critical juncture that had as a scope to attack and challenge government choices and decisions.

At this point, I would like to narrowly discuss the reason why I chose the term anti-institutional and not resistance to conceptualize oppositional social action during the years of crisis in Greece. As it happens with the concept of violence, resistance lacks conceptual clarity (Hollander and Einwohner, 2004: 533) resulting in the use of this term for the conceptualization of a very wide pool of actions (see also Hayward and Schuilenburg, 2014). Anti-institutional violence is a form of resistance as it is a form of political violence; however, it stands as a very specific resisting and violent form considering that the target of its actions is overly explicit for every actor involved. Observing the situation in Greece over the last years and referring to the available literature on the mobilizations of 2010-2015 it seems that intentions and perceptions of their actions are not necessarily shared among participants. However, what they do share, is the target that their actions are directed to, and that target is formal institutions and anything they represent. Thus, without extracting the resisting aspect of anti-institutional violence I do believe that its use as a concept is more accurate and provides the analytical specificity necessary for a deeper understanding of the actions to be discussed as well as of their interactive relation with other forms of violence presented in previous sections of this paper.

Mostly, critics of austerity argue that the way policies are designed target the most vulnerable and marginal groups in a society (Cooper and Whyte, 2017: 10). Even though this argument is correct, it simply marks the starting point of the social downturn caused by the crisis. In 2010, when the first mobilizations were fueled in Portugal, Italy, Ireland, Greece and Spain, the people participating were mostly low class - the first victims of austerity (Della Porta, 2017: 10). However, the people affected by austerity were not only those traditionally regarded as the vulnerable or marginal. The consequences of austerity were devastating to such a degree that alongside the groups usually found at the lower layers of a society, the middle class faced changes of historical proportions as well. That led to the second phase of mobilizations initiated in 2011, which was highly inspired by the Arab Spring, the Occupy movement and the occupation of Tahrir Square in Cairo (Karyotis and Rüdig, 2017: 4). The European movements of the Spanish Indignados and the Greek Aganaktismeni marked the rise of the so-called middle-class movements (Della Porta, 2017: 10) or, the movements of squares (see Diani and Kousis, 2014; Kaika and Karaliotas, 2014). The second phase lasted for a couple of months, making way for a third phase characterized by "diffused contention across the societal sphere" (Vogiatzoglou, 2016: 1). The fourth and final phase of mass mobilizations against austerity in Greece is attributed to the period between 
approximately 2012-2015, where as reported street protesting deteriorated, and focus was mostly attributed to social solidarity structures ${ }^{7}$ (ibid.).

What is important for the purposes of this paper is that especially after the second phase of mobilization people participating to oppositional movements and actions did not form a homogeneous group in terms of class division, political ideology, age, education, gender or in terms of mobilization/protesting experience (see Simiti, 2016: 42; Vogiatzoglou, 2016). Some groups belonged to the anarchist scene, some to the radical left, some to a traditional leftist party, some to the center-right, to the far right and others were called independent. The nonhomogeneity of the group does not merely support the extent of frustration caused due the introduction of austerity measures, it equally reflects the chaotic nature of the situation, leaving the people wondering as to where in the political spectrum they can find shelter against socio-economic oppression. A vivid example is the rise of leftist parties like Syriza in Greece, Podemos in Spain, Bloco de Esquerda in Portugal and La France Insoumise in France during mobilization against austerity in Europe - in an attempt to find an 'alternative' political party that would overturn decisions of previous governments (see Della Porta et al., 2017). Nevertheless, it simultaneously signified the rise of far-right movements and parties. For example, the rise of far-right organization Golden Dawn and its succession as a parliamentary party, was marked at the very beginning of the economic crisis in Greece. One of the reasons - not the only reason - of its succession is that they openly participated in anti-austerity mobilizations, while also organizing various events and gatherings to help people (merely Greeks) that were facing economic problems.

Ideological and class configuration do not stand as typical characteristics of movements of crisis. As evident from the above discussion, not every anti-austerity movement in Europe has broken out entirely from below, they are not characterized by an entirely independent/autonomous nature, they are not representing a specific class in society and they do not always share a common ideological basis. One might even argue that movements in crisis are dysmorphic. As Antonio Negri recently said about the most recent example of a movement of crisis, the French 'Gilets Jaunes', "what we have here is an artificial movement, a contradictory movement, divided internally along territorial, generational and class lines, among many others; what unifies it is the refusal to negotiate, the refusal to take a chance on the existing political structures". 8 This ideological and class heterogeneity not only proves the extent of opposition, but it most importantly proves the severity of the social harm caused by austerity, negatively influencing the quality of life of

7 Social solidarity structures usually refer to the establishment of social grocery stores, of social pharmacies and the provisions of meals, clothes and house supplies to people unable to sustain themselves and their families. Along those actions, some movements were also providing help to people in need of legal support for cases concerning their employment or housing.

8 Verso Books, French Insurrection: Antonio Negri on the Gilets Jaunes and the new wave of protests in France. Retrievable at: www.versobooks.com/blogs/4158-french-insurrection. 
numerous social groups, of social groups that prior to the crisis were considered as having nothing in common.

The discussion on anti-institutional movements has a couple of important implications when introduced to a theoretical discussion on violence. To begin with, even though Kerbo (1982) noted that movements of crisis usually tend to end in violent outbursts, not every movement and not every anti-austerity initiative ended up being violent. It is important to know how the anti-austerity mobilizations developed, however, in our analysis we need to be careful when distinguishing between violent and non-violent outbursts, unless we clarify what we term as violence - a discussion that leads back to the first section of this paper. It is true that in most cases and especially at moments of vast mobilizations, clashes with the police and cases of vandalism against public and private property were widely reported. Whether those performances were initiated by some members of protesting groups or came as a response to state repression through the police is debatable. What is interesting for the purposes of this paper which discusses violence, is that exploring the available literature on social movements, protests and violent kinds of contestation, I came across a number of discussions presenting those initiatives as common violence sponsored by radical groups (usually referring to anarchists) thus, studied under the theories of radicalization and terrorism.

As evident from the discussion above, it is time to challenge the notion that antiinstitutional violence merely comes from radicalized, organized groups of people who have a long-term strategy. Rather, it is suggested that violent outbursts in such instances should be conceptualized under theoretical concepts of political violence that refer to widespread social action and resistance, avoiding a rushed causal link with terrorism and political extremism. In the end, what is discussed in this section is the action of people against authority who are not normally mobilized; of people that are neither representatives of specific social classes nor of specific groups known to traditionally struggle. Thus, even in cases where mobilizations ended in violent outbursts, there is a chance that the actors involved were possibly not the so-called 'known' initiators or people with prior experience in violent confrontations. Through analyses that consider any violent outburst as an act of radicalism, the capacity of other non-radicalized groups of people to violently perform if they consider it necessary is underestimated. Simultaneously, the degree of responsibility of the state in leading non-radicalized people to violently perform in order to show their opposition is eliminated. One might even argue that by adopting this analysis we extract the agentic element of people that perform anti-institutional violence. The possibility of them intentionally (whatever that term entails and however it is being understood) initiating a violent interaction with the state should not be neglected nor undermined.

Going back to the analysis of Schinkel on the contemporary regimes of violence, the use of illegitimate violence by people is usually regarded as an active violence towards which the state reactively responses through the use of legitimate violence (Schinkel, 2013: 319). For the purposes of the discussion presented thus far in this paper, if we consider institutional violence as the one that preceded in 
time and anti-institutional as the response, then institutional violence is the active and anti-institutional the reactive. However, the state made use of its legitimate capacity to use violence against people during mobilizations through police repression, which is equally reactionary in nature as the people's reaction towards austerity politics. Thus, the discussion as developed suggests that whether violence is being labelled as legitimate/illegitimate, active/reactive is a matter of political construction, and viewpoints change based on who is the actor/initiator of a violent performance. Simultaneously, it highlights the interactive nature of violence which is highly communicative rather than co-existing. With the acknowledgment of the interactive element of violence it is not suggested that the analysis should be based on a causality that promotes a linear understanding of how violent performances escalate, or that one form necessarily precedes the other. Rather, the focus is on the existence of a violent system of interaction which confirms the existence of structural violence while it brings every other form of violence closer, explaining how they materialize at the same context during the same period of time.

\section{Conclusions}

Violence can take various forms and be identified as such based on the examination of different denominators. It could be an act, an omission, an arrangement, a process, an ideology. The aforementioned examples could be examined and identified as violence depending on their legality, legitimacy, visibility, brutality, means, outcomes or motives. In an endeavor to widen our field of vision and incorporate into the study of violence forms of non-physical nature or subject to non-physical outcomes - either committed by institutions and structures or by people opposing them - we need, as Jackman suggested, to free ourselves from inconsistencies of former discussions on violence and start looking at actions integral to social life that are possibly of a violent nature, however, traditionally not understood or studied as such (Jackman, 2002: 387). This paper is not meant to "report in other writers ... reluctance, or ineptitude, to resolve the confusion and put things straight" regarding the concept of violence (Bauman, 1995: 139). I, myself, choose to follow the 'dominant pattern of not defining violence' either (Maguire et al., 1997 in Schinkel, 2013: 311). The aim of this paper is rather to highlight the political, cultural and interactional dimensions of violence, not only as a concept but most importantly as a nature.

Social movement studies, conflict studies, criminology, political sociology and political philosophy have produced a useful toolkit of concepts that deal with different forms or expressions of structural, institutional and anti-institutional forms of violence. However, we still lack the knowledge to holistically understand the state of art in times where the power dynamics are changing on every level of the society at a high degree and speed. As argued, we still miss further developments in terms of how certain forms of violence are expressed and committed in recent times through politico-economic measures as well as the connection 
between neoliberal policies and the decline in civic and political rights that could possibly lead to a violent social action towards formal institutions.

Since in real life the forms of violence are fluid and not so easily delineated, this paper stands as a suggestion to re-evaluate our understanding of firstly the notion of each form separately as well as to bring the discussed forms together and suggest that they communicate and interact at a higher degree than the already existing academic scholarship suggests. Forms to be found at different levels of action are studied as if they are quite apart from each other. However, they are not isolated, neither in terms of characteristics and motives nor in terms of interaction. The one nourishes and sustains the other and their interaction is highly communicative rather than co-existing. In the end, what all these 'actors' have in common is the context, the situation they are trapped in; the framework within which they act, they interact and occasionally re-act. If that situation is violent in nature, their interaction will inescapably be violent as well. Using as a closure a passage from Louis Édouard's novel History of Violence, "The problem is not ... that in any interaction you have been forced into one or the other behavior, but that you have been forced to stay within the context of that interaction, within the

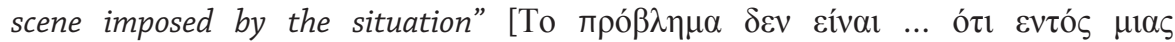

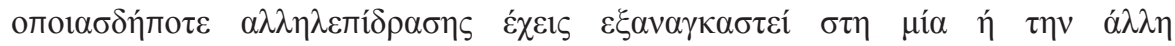

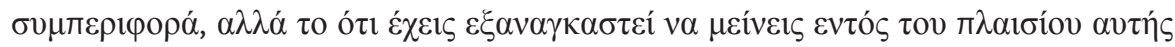

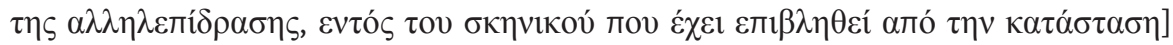
(Louis, [2016] 2019).

\section{Bibliography}

Barak, G. (2003). Violence and Nonviolence. Pathways to Understanding. Thousand Oaks: Sage.

Bauman, Z. (1995). Life in Fragments: Essays in Postmodern Morality. Oxford: Blackwell.

Benson, P. (2008). 'El Campo: Faciality and Structural Violence in Farm Labor Camps', Cultural Anthropology, 23(4), 589-629.

Böhm, M-L. (2018). The Crime of Maldevelopment: Economic Deregulation and Violence in the Global South. Routledge.

Bourdieu, P. (1977). Outline of a Theory of Practice. New York: Cambridge University Press.

Bourdieu, P. [1984] (1988) Homo Academicus. Stanford CA.

Bourdieu, P. (1997). Meditations pascaliennes. Paris: Seuil.

Brubaker, R. and Laitin, D.D. (1998). 'Ethnic and nationalist violence', Annual Review of Sociology, 24, 423-452.

Cooper, V. and Whyte, D. (Eds.). (2017). The Violence of Austerity. Pluto Press.

de Haan, W. J. M. (2008). 'Violence as an essentially contested concept', in S. Body-Gendrot, and P. Spierenburg (Eds.), Violence in Europe. Historical and Contemporary Perspectives (pp. 27-40). Dordrecht, New York: Springer.

della Porta, D. (2017). 'Global Diffusion of Protest. Riding the Protest Wave in the Neoliberal Crisis', in Donatella della Porta (Eds.), Global Diffusion of Protest (pp. 9-30), Amsterdam University Press.

della Porta, D., Fernández, J., Kouki, H. and Mosca, L. (2017). Movement Parties Against Austerity. Cambridge: Polity Press. 
Diani, M. and Kousis, M. (2014). 'The Duality of Claims and Events: The Greek Campaign against the Troika's Memoranda and Austerity, 2010-2012', Mobilization: An International Journal, 19(4), 387-404.

Farmer, P. (2004). 'An Anthropology of Structural Violence', Current Anthropology, 45(3), 305-325.

Gallie, W. B. (1956). 'Essentially contested concepts'. Proceedings of the Aristotelian Society, $56,167-198$.

Galtung, J. (1969). 'Violence, Peace and Peace Research', Journal of Peace Research, 6(3), 167-191.

Hayward, K., and Schuilenburg, M. B. (2014). 'To Resist = to Create? Some Thoughts on the Concept of Resistance in Cultural Criminology', Tijdschrift over Cultuur \& Criminaliteit, 4(1), 22-36.

Henry, S. (2000). 'What is school violence? An integrated definition', Annals of the American Academy of Political and Social Science, 567, 16-30.

Henry, S. and Lanier. M. M. (1998). 'The Prism of Crime: Arguments for an Integrated Definition of Crime', Justice Quarterly, 15, 609-627.

Henry, S. and Milovanovic, D. (1996). Constitutive Criminology: Beyond Postmodernism. Thousand Oaks, CA: Sage.

Hollander, J. and Einwohner R. (2004). 'Conceptualizing resistance', Sociological Forum, 19(4), 533-554.

Jackman, M. (2002). 'Violence in social life'. Annual Review of Sociology, 28, 387-415.

Kaika, M. and Karaliotas, L. (2014). 'The Spatialization of Democratic Politics: Insights from Indignant Squares', European Urban and Regional Studies, 23(4), 556-570.

Karyotis, G. and Rüdig, W. (2017). 'The Three Waves of Anti-austerity Protest in Greece, 2010-2015', Political Studies Review, 16(2), 158-169.

Kerbo, R. H. (1982). 'Movements of 'Crisis' and Movements of 'Affluence' A Critique of Deprivation and Resource Mobilization Theories', Journal of Conflict Resolution, 26(4), 645-663.

Kleinman, A., Das, V. and Lock, M. (Eds.) (1997). Social Suffering. Berkeley: University of California Press.

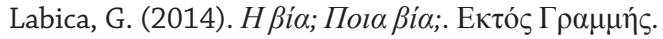

Levi, M. and Maguire, M. (2002). 'Violent crime', in: The Oxford Handbook of Criminology (pp. 795-843). Oxford: Oxford University Press.

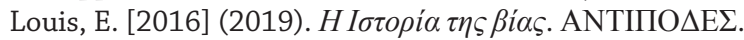

Maguire, M., Morgan, R. and Reiner, R. (Eds.) (1997). Oxford Handbook of Criminology. Oxford: Oxford University Press.

Mavridis, S. (2018). 'Greece's Economic and Social Transformation 2008-2017', Soc. Sci. MDPI, 7(1).

McMurty, J. (1999). The cancer stage of capitalism. London: Pluto Press.

Mukherjee, J. S., Barry, D. J., Satti, H., Raymonville, M., Marsh, S. and Smith-Fawzi, M. K., (2011). 'Structural Violence: A Barrier to Achieving the Millennium Development Goals for Women', Journal of Women's Health, 20(4), 593-597.

Nixon, R. (2011). Slow Violence and the Environmentalism of the Poor. Cambridge, MA: Harvard University Press.

Quesada, J. (2009). 'The Vicissitudes of Structural Violence: Nicaragua at the Turn of the Twenty-First Century', in Rylko-Bauer, B., Whiteford, L. and Farmer, P. (Eds.) Global Health in Times of Violence (pp. 157-180). Santa Fe: School for Advanced Research Press.

Riches, D. (Ed.) (1986). The Anthropology of Violence. Oxford: Basil Blackwell. 
Ruggiero, V. (2006). Understanding Political Violence. London/New York: Open University Press / McGraw-Hill.

Ruggiero, V. (2017). 'Political violence and crime', in Pontell, H. N. (Ed.) Oxford Research Encyclopedia of Criminology and Criminal Justice. Oxford University Press. Online version: https://eprints.mdx.ac.uk/22202/3/Political\%2520violence\%2520and\%2520 crime.pdf.

Rylko-Bauer, B. and Farmer, P. (2016). 'Structural Violence, Poverty and Social Suffering', in Brandy, D. and Burton, M. L. (Eds.) The Oxford Handbook of the Social Science of Poverty (pp. 47-74). Oxford University Press.

Sanchez, M. (2006). 'Insecurity and Violence as a New Power Relation in Latin America', Annals of the American Academy of Political and Social Science, 606, 178-195.

Sapiro, G. (2015). 'Bourdieu, Pierre (1930-2002)', in Wright D. J. (Eds.) International Encyclopedia of the Social \& Behavioral Sciences (Second Edition) (pp. 777-783). Elsevier.

Schinkel, W. (2005). Aspects of Violence. Unpublished doctoral dissertation. Rotterdam: Erasmus University.

Schinkel, W. (2013). 'Regimes of Violence and the Trias Violentiae', European Journal of Social Theory, 16(3), 310-325.

Simiti, M. (2016). 'Rage and Protest: The Case of The Greek Indignant Movement', Contention: The Multidisciplinary Journal of Social Protest, 3(2), 33-50.

Singer, M. and Erickson, P. I. (2011). 'Introduction', in Singer, M and Erickson, P. I. (Eds.) A Companion to Medical Anthropology (pp. 1-5). Malden, MA: Wiley-Blackwell.

Smelser, N. J. (1963). Theory of collective behaviour. New York: The Free Press.

Vogiatzoglou, M. (2016). 'Anti-austerity mobilization and protest 2010-2014 in Greece', in della Porta, D., M. Andretta, T. Fernandes, E. Romanos, F. O’Connor and M. Vogiatzoglou (Eds.) Late Neoliberalism and its Discontents in the Economic Crisis. (pp. 99-129). Cham: Palgrave Macmillan.

Weber, M. [1919] (2015). Weber's Rationalism and Modern Society. (T. Waters and D. Waters Trans. and Eds.). New York, NY: Palgrave Macmillan.

Winter, D. and Leighton, C. D. (2001). 'Structural Violence: Introduction', in Christie, D. J., Wagner, R. V. and DuNann Winter, D. (Eds.) Peace, Conflict, and Violence: Peace Psychology for the 21st Century (pp. 99-101). Upper Saddle River, NJ: Prentice Hall. 